\title{
Environment in Water Issue and Management
}

\author{
Dr. L.P Parmar \\ Asst. Professor, Economics Department, \\ Navjivan Arts and Commerce College, Dahod, India
}

\section{INTRODUCTION}

As human civilization progressed man started altering the natural environment in the pursuit of creating an economic, social and cultural environment of his own choice. This slowly resulted in the depletion of natural resources and degradation of Environment. Further with increased population and urbanization and developmental project have placed a lot of strain on natural resources and also on the environment. Nov, situation is deteriorating so fact especially in the last few decades that environmental issues are posing threat to human health and his very existence.

In recent past, numerous environmental problems have become critically significant for mankind to enumerate some like air, water and land pollution, spread of toxic wastes, deforestation, mass extinction of wild life, problems of human settlement. Environment in water issues and their impact is not confined to their source area alone but spills over far and wide. Thus environmental issues are intrinsically global in nature.

\section{Environment in Water Issue}

Water is life - foundation of health, hygiene, progress and prosperity. Total quantity of water on the planet Earth his fixed and constant. It may be in the form of water as vapor, moisture, ice or snow. Population is projected to increase for another decades before stabilizing. At global level the population double since 1940 but use of fresh water increased fourfold in the same period. This is indicative of future trend and a warning as well. A day is bound to come when total availability of water in some regions will fall of short of demand. Beyond that day, the only way is going to be the efficient management of available water. There are only four major elements of this management effort will be

$\rightarrow$ Efficient harvesting.

$\rightarrow$ Careful conservation.

$\rightarrow$ Economic use.

$\rightarrow$ And recycling the waste water.

There is ample evidence to show that lately the awareness about water on the part of common man has considerably increased but still much remains to be done. Before we try to do anything about water management we should know following things about water.

$\rightarrow$ One drop of oil can make up to 25 liters of water undrinkable.

$\rightarrow 70 \%$ of the world water is used for agriculture, $22 \%$ for industry and $8 \%$ domestic use.

$\rightarrow$ Law and middle income countries use $82 \%$ of their water use for agriculture $10 \%$ for industry and $8 \%$ for domestic use.

$\rightarrow$ High income countries use $30 \%$ of their water use in agriculture, $59 \%$ for industry and $11 \%$ for domestic use.

$\rightarrow$ A person is able to survive I month without food 5 to 7 days without water.

$\rightarrow$ A water foot print or Virt water is the amount of water used in the entire production and of a specific product. For example,

- I kilogram of beef has a water footprint of 16000 liters. 
- I sheet of paper has a water footprint of 10 liters.

- I cup of tea has a water footprint of 35 liters.

- I kilogram wheat has a water footprint of 1000 liters.

- I kilogram of rice has a water footprint of 3000 to 4000 liters.

- I kilogram of steel production has a water footprint of 250 liters.

$\rightarrow$ Water required for single vegetarian meal is 1000 liters.

$\rightarrow$ Water required for single non-vegetarian meal is 3500 liters.

$\rightarrow \quad$ It takes 94.5 to 189.3 liters of water to take a 5 minutes shower.

$\rightarrow \quad 7.6$ to 26.5 liters to flush a toilet.

$\rightarrow 7.6$ liters to brush one`s teeth.

$\rightarrow \quad 75.7$ liters to hand wash dishes.

$\rightarrow 6000$ children die each day from preventable water diseases.

To think of life without water is not only unimaginable but frightening!

Basic necessities of human existence food, fabric and shelter are not possible without water.

\section{No Water - No Life.}

Various religious scriptures have not only emphasized the importance of water but have incorporated prayers addressed to water.

Life was created out of five basic elements Water, Earth, Air, Fire and Space. - Rigved

Water is life, Water is food. - Yajurvaved

The great thinker Mahatma Gandhi said... "Don't use money like a water but water like money".

\section{Water Availability}

Total area of the planet Earth is estimated as 510 million square kilometres. Ocean is occupying as area of 360 million square kilometres. Virtually all of these human uses require fresh water. $97.5 \%$ of water on the Earth is salt water, leaving only $2.5 \%$ as fresh water of which over two thirds is frozen in glaciers and polar ice caps is $70 \%$. The remaining unfrozen fresh water is mainly found as groundwater is $30 \%$, among the fresh water only $0.5 \%$ is used by human and other animal on Earth. That is only $0.07 \%$ of hole water on the Earth is useful for humans with only a small fraction present above ground water. Fresh water is a renewable resource, yet the world's supply of clean, fresh water is steadily decreasing. Water demand already exceeds supply in many parts of the world, and as world population continues to rise at an unprecedented rate, many more areas are expected to experience this imbalance in the near future. The framework for allocating water resources to water uses (where such a framework exists) is known as water rights.

\section{Geography and Population}

India is located in southern Asia and has a total area of $32,87,590$ square kilometres, it is the world's largest peninsula and seventh largest country in world. It has some 5600 kilometres of coastline on the Arabian Sea, Indian Ocean and Bay of Bengal. The peninsula can be divided in to the three regions. The peninsular India, located south of vindhya and satpura mountain ranges. The plains of Indus of Ganges Rivers and the mountainous terrain of Himalayas.

\section{Water Resources}

Water resources are sources of water that are useful or potentially useful to humans. Uses of water include agricultural, industrial, household, recreational and environmental activities. The two main sources of water in India are rainfall and the snowmelt of glaciers in the Himalaya. Although reliable data on snow cover in India are not available, It is estimated that some 5,000 glaciers cover about $43,000 \mathrm{~km}$ in the Himalayas.

With a total volume of locked water estimated at $3,870 \mathrm{~km}$. considering that about $10000 \mathrm{~km}$ are located in Indian Territory, the total water yield from snowmelt contributing to the river runoff in India may be of the order of $200 \mathrm{~km} / 3$ year.

Although snow and glaciers are poor producers of fresh water, they are good distributors as they yield at the time of need, in the hot season. Indeed, about $80 \%$ of the flow of rivers in India occurs during the four to five months of the southwest monsoon season.

\section{Environmental Issues and Management}

In recent past natural resources are under increasing pressure, threatening, public health and development. As the world's population grows, improving living standards without destroying the environment is a global challenge. Most developing countries with rapid population growth face the urgent need to 
improve living standards. As we exploit the nature to meet the present needs. We are destroying the resource needs for the future. In the past decade in every environmental sector, conditions have either failed to improve, or they are worsening.

\section{Forests}

$>$ Nearly half of the world`s original forest cover has been lost.

$>$ Each year millions of hectares of forests are cut, bulldozed or burned.

$>$ Forests provide over 400 billion US\$ to the world economy annually and are vital to maintaining healthy ecosystems.

Current demand for forest products may exceed the limit of sustainable consumption by $25 \%$.

\section{Coastlines and Oceans}

$>$ Half of all coastal ecosystems are pressured by high population densities and urban development.

$>$ A tide of pollution is rising in the world's seas.

$>$ Ocean fisheries are being overexploited and fish catches are down.

\section{Bio-Diversity}

$>$ Earth's biological diversity is crucial to the continued vitality of Agriculture and medicine, and perhaps even to life on Earth itself.

$>$ Human activities are pushing many thousands of plant and animal Species into extinction.

$>$ Two of every three species is estimated to be in decline.

\section{Public Health}

Unclean water along with poor sanitation kills over 12 million people each year. Water pollution is a serious problem everywhere.

$>$ Air pollution kills nearly 3 million people. Air pollution, already a serious problem in cities, is becoming worse as urban population grow and the number of motor vehicles rises.

$>$ Heavy metals and other contaminants also cause health problems.

\section{Fresh Water}

Supply of fresh water is limiting, since the demand is soaring as population grows and percapital use rises.
By 2025, when world population is projected to be 8 billion, nearly 38 countries containing 3 billion people will face freshwater shortages.

\section{Water Pollution}

A large quantity of industrial effluent is generated in cities. This need to treated to remove harmful substances before letting into the river. However, this is often not practiced because of the high cost. Such untreated effluent may poison fish, other animals and plants living in water. Sewage containing harmful germs and chemicals can contaminate the sources of drinking water. The treated effluent and sewage can be used for irrigating fruit and forestry trees.

\section{Chemical Pollution}

Use of agro-chemicals has become a common practice in agriculture of these chemicals. Consumption of fruits and vegetables, harvested soon after the chemical spray is another health hazards.

To avoid this, it is necessary to educate farmers to use agro-chemicals safely and only when needed. Plant products like oil and cake of neem and pongamia, which are non-toxic to us, can be used to control many crop pests. In irrigated fields, when farmers apply large quantities of chemical fertilizers and pesticides, a part of these chemicals may dissolve in water and percolate into the wells. Thus, the water may get polluted. Drinking this water may cause sickness. In such areas, we need to persuade farmers to reduce the doses of agro-chemicals. Effluents from sugar factories and other industries let in the field may also pollute drinking water in a similar way. Such factories should be told to treat the effluents properly.

The environmental protection Act of 1986 came in to force soon after Bhopal gas tragedy and is considered as it fills many lacunae in the existing environmental legislations. There after a large number of environmental legislations come in to existence. Existing Indian environmental legislations can be grouped in following four categories: 1) Water Acts, 2) Air Acts, 3) Forest \& Wild life Acts, 4) General Acts.

\section{CONCLUSION}

Bureaucracy and government need to consider environment in water issues practice not just in theory or law. Environmental ministry must be given higher importance to environment saving measures. 
Industries need to take a long-term approach rather than pushing for quick-fix solutions. The best way to purity the polluted water is to grow more trees, wherever we can. Factories should be forced to install pollution control devices. There are many initiatives that India can take to reduce pollute water emission without sacrificing its priority of economic development.

\section{REFERENCES}

1) Sinha A.K : 'Global Environmental protection', Indus Publication, New Delhi.

2) Tyagi M.H : 'Global Environmental Issues', Raj Publishing House, Jaipur.

3) Mathur A.K : 'Environmental Problems \& Measures', Gaurav Publication, New Delhi.

4) Hydrological and Environmental Departments.

5) Water Commission of India.

6) National Water Development Agency. 